\title{
JURNAL \\ KEDOKTERAN DAN KESEHATAN \\ Pengaruh Senam Yoga terhadap Kesiapan Fisik dan \\ Psikologis dalam Menghadapi Persalinan di BPM \\ Lasmitasari, S.ST
}

\author{
Ni Wayan Kurnia Widya Wati ${ }^{1}$, Salasiah Supiyati ${ }^{2}$, Khairiatul Jannah ${ }^{3}$ \\ 1,2,3 Program Studi Kebidanan, STIKES Husada Borneo \\ J1. A. Yani Km 30,5 No.4 Banjarbaru, Kalimantan Selatan \\ Email: niwayan.husadaborneo@gmail.com
}

\begin{abstract}
ABSTRAK
Yoga merupakan sistem kesehatan yang bersifat holistik baik jiwa, pikiran dan tubuh yang dilakukan dengan sistem gerak yang halus tidak menghentak dengan panduan pernafasan yang harmonis. Berdasarkan hasil studi pendahuluan yang penulis lakukan di Bidan Praktik Mandiri dengan wawancara, sebagian besar ibu hamil belum mengetahui manfaat senam yoga pada masa kehamilan, hal ini dilihat dari rutin atau tidaknya ibu melakukan senam yoga di BPM Lasmitasari, S.ST sehingga ibu masih merasakan kecemasan dan susah tidur. Penelitian ini bertujuan untuk mengetahui pengaruh senam yoga ibu hamil terhadap kesiapan fisik dan psikologis dalam menghadapi persalinan di BPM Lasmitasari, S.ST tahun 2016. Penelitian ini menggunakan metode analitik dengan dengan rancangan cross sectional. Penelitian ini dilakukan terhadap 40 responden ibu hamil yang mengikuti senam yoga hamil. Berdasarkan hasil uji statistik dengan menggunakan chi-square menunjukkan bahwa dengan $\alpha<0.05$ didapatkan $\rho=0.00$ yang berarti kurang dari 0.05 maka dapat disimpulkan bahwa hipotesis diterima yang artinya ada pengaruh senam yoga ibu hamil terhadap kesiapan fisik dan psikologis dalam menghadapi persalinan di BPM Lasmitasari, S.ST tahun 2016. Diharapkan dapat menjadi bahan untuk menambah pengetahuan mengenai senam yoga hamil dan ibu hamil bisa melakukan senam yoga hamil secara teratur karena senam yoga hamil mempunyai banyak manfaat bagi ibu hamil terhadap kesiapan fisik dan psikologis dalam menghadapi persalinan.
\end{abstract}

Kata Kunci: senam yoga, kesiapan fisik dan psikologis, ibu hamil

\section{Effect of Gymnastic Yoga on Physical and Psychological Preparedness in Facing the Childbirth in BPM Lasmitasari, S.ST}

\begin{abstract}
Yoga is a holistic health system of good spirit, mind and body It's done by a smooth motion system snaps with mounth breathing guide with a harmony. Based on the results of preliminary studies that conducted by the author in BPM by interviews, most of pregnant mothers did not know the benefits of yoga exercises during pregnancy, it can be seen from routine whether or not the mother doing yoga exercises in BPM, so the mothers still feel anxiety and insomnia. The objective of this study aims to determine the effect of yoga exercises for pregnant women against physical and psychological readiness of labor in BPM Lasmitasari, S.ST 2016. This study uses an analytical method with cross sectional design. This study was conducted on 40 pregnant women respondents who follow yoga exercises. Based on the statistical results by
\end{abstract}


using chi-square showed that $\alpha<0.05$ obtained $\rho=0.00$, which means less than 0.05 it can be concluded that hypothesis was accepted which means there is the influence of yoga exercises pregnant women against physical readiness and psychological labor in BPM Lasmitasari, S.ST 2016. This study is expected to increase the knowledge do yoga exercises for pregnant women on a regular basis to provide benefits to the physical and psychological readiness of pregnant women in the face of labor.

Keywords: yoga exercises, physical and psychological readiness of labor

\section{Pendahuluan}

Salah satu indikator untuk mengukur derajat kesehatan adalah kematian ibu dan angka kematian perinatal. Menurut World Health Organisation (WHO) angka kematian dan kesakitan ibu hamil, melahirkan dan nifas masih merupakan masalah besar yang terjadi di negara berkembang termasuk Indonesia. Di negara miskin terdapat sekitar 25-50\% kematian usia subur disebutkan masih terkait dengan kehamilan, persalinan dan nifas. Menurut WHO diperkirakan seluruh dunia terdapat sekitar 536.000 wanita meninggal dunia akibat masalah persalinan. Dari jumlah tersebut $99 \%$ di antaranya terjadi di negara-negara berkembang. Mayoritas dan morbiditas pada waktu hamil dan bersalin adalah masalah besar di negara berkembang. Yoga memang sangat populer di dunia sekarang ini, sebagai salah satu olahraga yang menyentuh tubuh. Selain untuk mengurangi stres dan meregangkan otot, manfaat yoga bisa mengecilkan perut dan membuat tubuh langsing ideal ${ }^{1}$.

Yoga di Indonesia mulai di kenal sejak tahun 1990, perkembangannya di Indonesia, Jakarta khususnya terjadi pertengahan ketika terjadi krisis ekonomi dimana banyak masyarakat dilanda stres. Ketika pengobatan medis tidak cukup ampuh mereka mulai berpaling ke yoga sebagai penyembuhan alami. Prenatas yoga khususnya ibu hamil dengan katagori yang disesuaikan dengan usia kehamilan ibu. Latihan intinya yaitu deep breath and movement sebuah proses bernapas yang dilakukan melalui kesadaran, tujuannya membantu ibu hamil saat proses melahirkan ${ }^{2}$.

Selama masa kehamilan ibu hamil mengalami perubahan fisik dan psikologis yang dapat menimbulkan ketidaknyamanan terutama trimester II dan III seperti dispnea, insomnia, epulsi, sering buang air kecil, tekanan dan ketidaknyamanan pada perineum, nyeri pinggang, konstipasi, varises, mudah lelah, kontraksi braxton hicks, kram kaki, edema pergelangan kaki (non pitting) dan perubahan mood serta peningkatan 
Ni Wayan Kurnia Widya Wati, Salasiah Supiyati, Khairiatul Jannah, Pengaruh Senam Yoga terhadap Kesiapan Fisik dan Psikologis dalam Menghadapi Persalinan di BPM Lasmitasari, S.ST

kecemasan $^{3}$. Perubahan fisik yang terjadi seperti rasa mual dan muntah di pagi hari, meningkatnya frekuensi buang air kecil, pembesaran usus, nyeri punggung dan pergerakan janin. Sedangkan perubahan emosi meliputi kecemasan, rasa takut dan depresi ${ }^{4}$. Rasa tidak nyaman selama kehamilan dan kecemasan menghadapi persalinan menyebabkan gangguan pola tidur pada wanita hamil dan salah satu kondisi yang menyebabkan gangguan tidur pada wanita hamil adalah perubahan fisik dan emosi selama kehamilan ${ }^{5}$.

Pada umumnya wanita yang sedang hamil takut mengahadapi proses persalinan karena rasa sakit yang menimbulkan rasa takut dan cemas. Hal ini dapat menimbulkan ketegangan jiwa dan fisik yang akan mengakibatkan kakunya otot-otot dan persendian yang tidak wajar. Stres atau kecemasan tersebut terkait dengan berbagai hasil kehamilan, rasa sakit dan keluhan somatik lain yang sering terjadi dengan gangguan mood pada ibu hamil ${ }^{6}$.

Gangguan psikologis pada ibu hamil juga dapat berpengaruh buruk terhadap perkembangan janin. Pada ibu hamil yang mengalami stres yang berkepanjangan dapat menimbulkan hambatan perkembangan pada janin termasuk gangguan emosi setelah kelahiran, bila stres pada ibu tidak tertangani dengan baik meskipun dengan asupan nutrisi yang baik. Gangguan psikologis tersebut dapat meningkatkan resiko terjadinya komplikasi dalam persalinan sehingga diperlukan pencegahan dengan beberapa metode untuk meringankan dan mempersiapkan ibu dalam menjaga kehamilan dan proses persalinannya. Pencegahan komplikasi persalinan bertujuan untuk membuat ibu dan bayi baru lahir dapat memperoleh derajat kesehatan yang tinggi dan terhindar berbagai ancaman atau fungsi reproduksi ${ }^{7}$.

Latihan fisik yang dapat dilakukan selama masa kehamilan salah satunya adalah senam hamil. Senam hamil memiliki beberapa metode latihan salah satunya adalah dengan pendekatan metode latihan yoga yang sangat baik untuk ibu hamil sebab dapat meringankan pegal-pegal dan meredam emosi yang tidak stabil ${ }^{8}$. Berlatih senam hamil yoga pada masa ini merupakan salah satu solusi self help yang menunjang proses kehamilan, kelahiran dan bahkan pengasuhan pengasuhan anak yang dapat melakukan dalam kelas antenatal, yang merupakan sarana belajar kelompok tentang kesehatan ibu hamil, dalam bentuk tatap muka yang bertujuan meningkatkan pengetahuan dan keterampilan mengenai kehamilan, persalinan, perawatan tali pusat bayi baru lahir².

Senam hamil yoga bagi kehamilan memfokuskan perhatian pada ritme nafas, mengutamakan kenyamanan serta keamanan dalam berlatih sehingga memberikan banyak manfaat ${ }^{8}$. Manfaat senam hamil yoga pada ibu hamil yaitu dapat meningkatkan aliran darah dan nurtrisi bagi janin secara adekuat serta berpengaruh juga pada organ reproduksi dan 
panggul (memperkuat otot perineum) ibu untuk mempersiapkan kelahiran anak secara alami. Selain itu latihan yoga selama hamil dapat meringankan edema dan kram yang sering terjadi pada bulan-bulan terakhir kehamilan, membantu posisi bayi dan pergerakan, meningkatkan sistem pencernaan dan nafsu makan, meningkatkan energi dan memperlambat metebolisme untuk memulihkan ketenangan dan fokus, mengurangi rasa mual, morning sickness dan suasana hati, meredakan ketegangan di sekitar leher rahim dan jalan lahir, yang berfokus pada pembukaan pelvis untuk mempermudah persalinan, membantu dalam perawatan pasca kehamilan dengan mengembalikan uterus, perut dan dasar panggul, mengurangi ketegangan, cemas dan depresi selama hamil, persalinan nifas dan ketidak nyamanan payudara ${ }^{9}$. Senam hamil yoga memiliki lima cara yaitu fisik yoga, pernafasan (pranayama), postitions (mudra), meditasi dan deep relaksi yang dapat digunakan untuk mendapatkan manfaat selama kehamilan yang dapat membantu dalam memastikan bayi yang sehat $^{10}$.

Bidan Praktik Mandiri Lasmitasari, S.ST terletak di jalan Karang Rejo Komplek Mustika Indah Blok C no. 24 Kelurahan Guntung Manggis Kecamatan Landasan Ulin Kabupaten Banjarbaru Kota Madya Provinsi Kalimantan Selatan, BPM ini mempunyai izin penelitian sejak tahun 2013 dan pelayanan yang diberikan adalah salah satunya senam yoga pada ibu hamil. Jumlah data ibu hamil trimester II dan trimester III yang datang ke BPM untuk memeriksakan kehamilannya dari bulan Januari-Mei 2016 sebanyak 581 orang. Berdasarkan hasil studi pendahuluan yang penulis lakukan di Bidan Praktik Mandiri dengan wawancara terdapat $11 \mathrm{ibu}$ hamil yang melakukan senam yoga. Sebagian besar 8 orang $(72.7 \%)$ ibu hamil belum mengetahui manfaat senam yoga pada masa kehamilan, hal ini dilihat dari rutin atau tidaknya ibu melakukan senam yoga di BPM Lasmitasari, S.ST sehingga ibu masih merasakan seperti pegal-pegal, sakit pinggang, cemas dan sulit tidur. Sedangkan 3 orang (27.3\%) sudah mengetahui manfaat dari senam yoga dalam kehamilan. Sehingga ibu tidak merasakan kecemasan, tidur dengan nyaman dan lebih rileks dalam menghadapi persalinan nanti.

\section{Metode Penelitian}

Jenis penelitian ini adalah penelitian analitik. Populasi pada penelitian ini adalah seluruh ibu-ibu hamil yang mengikuti senam yoga ibu hamil di Bidan Praktik Mandiri Lasmitasari, S.ST. Penentuan populasi didasarkan atas semua jumlah ibu hamil trimester II dan trimester III yang melakukan senam yoga di Bidan Praktik Mandiri Lasmitasari, S.ST. Jumlah populasi dari penelitian ini sebanyak 40 orang. Variabel dalam penelitian ini adalah pengaruh senam yoga ibu hamil dan kesiapan fisik dan psikologis dalam menghadapi persalinan. Teknik pengumpulan data 
Ni Wayan Kurnia Widya Wati, Salasiah Supiyati, Khairiatul Jannah, Pengaruh Senam Yoga terhadap Kesiapan Fisik dan Psikologis dalam Menghadapi Persalinan di BPM Lasmitasari, S.ST

DOI : $10.24853 /$ jkk.14.1.39-47

dalam penelitian ini berupa data primer dan data sekunder.

\section{Hasil}

\section{Senam Yoga Ibu Hamil}

Dari tabel 1 menunjukan bahwa dari 40 orang ibu hamil yang melakukan senam yoga sebagian besar 25 responden (62.5\%) melakukan senam yoga teratur.

Tabel 1. Dsitribusi Frekuensi Responden Berdasarkan Ibu yang Melakukan Senam Yoga di BPM Lasmitasari, S.ST Tahun 2016

\begin{tabular}{llcc}
\hline No. & Senam Yoga & $\begin{array}{c}\text { Frekuensi } \\
(\mathbf{n})\end{array}$ & $\begin{array}{c}\text { Presentase } \\
(\mathbf{\%})\end{array}$ \\
\hline 1. & Teratur & 25 & 62,5 \\
\hline 2. & Tidak teratur & 15 & 37,5 \\
\hline & Total & 40 & 100 \\
\hline
\end{tabular}

\section{Kesiapan Menghadapi Persalinan}

Dari tabel 2 menunjukkan bahwa dari 40 orang ibu hamil sebagian besar kesiapan fisik dan psikologis yang siap menghadapi persalinan sebanyak 26 responden $(65 \%)$.

Tabel 2. Distribusi Frekuensi Responden Berdasarkan Kesiapan Fisik dan Psikologis dalam Menghadapi Persalinan di BPM Lasmitasari, S.ST

\begin{tabular}{llll}
\hline No. Kesiapan Fisik dan Psikologis & n & $\%$ \\
\hline
\end{tabular}

\begin{tabular}{llcc}
\hline 1. & Siap & 26 & 65 \\
\hline 2. & Kurang siap & 14 & 35 \\
\hline & Total & 40 & 100 \\
\hline
\end{tabular}

Pengaruh senam yoga pada ibu hamil dengan kesiapan fisik dan psikologis menghadapi persalinan. Berdasarkan tabel 3 menunjukan bahwa sebagian besar responden yang melakukan senam yoga teratur mempunyai kesiapan fisik dan psikologis siap sebanyak 22 responden dan sebagian besar responden yang melakukan senam yoga tidak teratur mempunyai kesiapan fisik dan psikologis kurang siap sebanyak 11 responden.

Tabel 3. Pengaruh Senam Yoga pada Ibu Hamil dengan Kesiapan Fisik dan Psikologis dalam Menghadapi Persalinan di BPM Lasmitasari, S.ST

\begin{tabular}{|c|c|c|c|c|c|c|c|}
\hline \multirow{3}{*}{ No. } & \multirow{3}{*}{ Senam yoga } & \multicolumn{4}{|c|}{$\begin{array}{c}\text { Kesiapan Fisik dan } \\
\text { Psikologis }\end{array}$} & \multirow{2}{*}{\multicolumn{2}{|c|}{ Jumlah }} \\
\hline & & \multicolumn{2}{|c|}{ Siap } & \multicolumn{2}{|c|}{ Kurang siap } & & \\
\hline & & $\mathbf{N}$ & $\%$ & $\mathbf{n}$ & $\%$ & $\mathbf{n}$ & $\%$ \\
\hline 1. & Teratur & 22 & 55 & 3 & 7.5 & 25 & 62.5 \\
\hline 2. & Tidak teratur & 4 & 10 & 11 & 27.5 & 15 & 37.5 \\
\hline Tota & & 26 & 65 & 14 & 35 & 40 & 100 \\
\hline
\end{tabular}

Hasil uji statistik dengan Chi-Square dengan $\alpha<0.05$ didapatkan $\mathrm{p}=0.00$ berarti kurang dari 0.05 maka dapat disimpulkan bahwa hipotesis diterima yang artinya ada pengaruh yang bermakna antara senam yoga ibu hamil dengan kesiapan fisik dan psikologis menghadapi persalinan.

\section{Pembahasan}

\section{Senam Yoga Ibu Hamil}

Berdasarkan tabel 1 menujukan bahwa dari ibu yang melakukan senam yoga secara teratur sebayak 25 responden $(62.5 \%)$ dan ibu yang melakukan senam yoga tidak teratur sebanyak 15 responden (37.5\%). Yoga merupakan salah satu gerakan seni oleh tubuh dan pernapasan yang berasal dari India. Yoga bisa dilakukan oleh siap saja termasuk oleh ibu hamil. Yoga hamil membantu ibu untuk terhubung dengan bayi dan tubuhnya sendiri melalui latihan mendalam dan membangun 
kewaspadaan pada saat proses kelahiran atau melahirkan ${ }^{11}$.

Menurut Widdiwson senam hamil yoga adalah bagian dari perawatan antenatal. Senam hamil berguna untuk mengoptimalkan keseimbangan fisik, memelihara kesehatan kehamilan, menghilangkan keluhan yang terjadi karena perubahan-perubahan akibat proses kehamilan dan mempermudah persalinan ${ }^{12}$.

Filosofi yoga mengambarkan pernyataan antara pikiran, tubuh dan roh, pernyataan individu dan seluruh ciptaannya. Pernyataan individu dan daya luasnya yoga lebih dari sekedar latihan fisik karena yoga adalah jalan hidup, yaitu jalan hidup ketika menjadi manusia di dunia. Yoga adalah suatu filosofi, seni dan ilmu berawal dari sejarah India ${ }^{13}$.

Kesiapan Fisik dan Psikologis Ibu Hamil Dalam Menghadapi Persalinan

Berdasarkan tabel 2 didapat bahwa ibu hamil yang siap menghadapi persalinan 26 responden (65\%) dan ibu hamil yang kurang siap menghadapi persalinan 14 responden (35\%). Perubahan-perubahan fisik yang sering ditemukan pada trimester III yaitu pembesaran perut sesuai dengan tuanya kehamilan, hearburn atau disebut juga nyeri perut kiri atas sering dialami oleh ibu hamil akibat tubuh menghasilkan dan menyiapkan cairan tambahan selama kehamilan, akibatnya banyak bumil yang mengalami bengkak, terutama di akhir kehamilan. Bengkak sering timbul di kaki, tumit, dan wajah akibat dari penekanan pembahasan uterus pada pembuluh vena mengakibatkan darah baik dari bagian bawah tubuh ${ }^{8}$.

Ibu hamil pertama tidak jarang memiliki pikiran yang menggangu, sebagai pengembangan reaksi kecemasan terhadap cerita yang diperolehnya. Semua orang selalu mengatakan bahwa melahirkan itu sakit sekali. Oleh karena itu, muncul ketakutanketakutan pada ibu hamil pertama yang belum memiliki pengalaman bersalin. Adanya pikiran-pikiran seperti melahirkan yang akan selalu diikuti dengan nyeri kemudian akan menyebabkan peningkatan kerja sistem syaraf simpatetik. Hormon yang juga dikenal sebagai hormon adrenalin ini memberi tenaga pada individu serta mempersiapkan secara fisik dan psikis. Adanya peningkatan hormon adrenalin dan noradrenalin atau epinefrin dan norepinefrin menimbulkan disregulasi biokimia tubuh, sehingga muncul ketegangan fisik pada diri ibu hamil. Ibu hamil menjadi mudah marah atau tersinggung, gelisah, tidak mampu memusatkan perhatian, ragu-ragu, bahkan kemungkinan ingin lari dari kehidupan 10 .

Persiapan fisik yang perlu di perhatikan adalah dengan melakukan olah raga senam yoga hamil, karena seorang perempuan memerlukan fisik yang fit untuk melahirkan. Senam hamil yoga ini hanya bisa dilakukan ibu hamil trimester II dan trimester III. Namun, yang perlu dipertahankan tidak semua kondisi ibu hamil dapat melakukan 
Ni Wayan Kurnia Widya Wati, Salasiah Supiyati, Khairiatul Jannah, Pengaruh Senam Yoga terhadap Kesiapan Fisik dan Psikologis dalam Menghadapi Persalinan di BPM Lasmitasari, S.ST

treatment ini, sehingga disarankan melakukan konsultasi terlebih dahulu dengan dokter pendamping kandungan. Ada dua tipe kondisi wanita yang tidak bisa melakukan senam hamil, yaitu yang bersifat relatif (riwayat kebidanan jelek,janin kembar, menderita diabetes, letak bayi sungsang). Sementara yang bersifat mutlak tidak boleh dilakukan senam hamil adalah (menderita penyakit jantung, hipertensi, resiko kelahiran prematur. Latihan senam yoga ini harus dihentikan jika terjadi keluhan nyeri di bagian dada, nyeri kepala dan nyeri persendian, kontraksi rahim yang sering, keluar cairan, denyut jantung meningkat >140/menit, kesulitan untuk berjalan, dan mual, serta muntah yang menetap ${ }^{10}$.

Persiapan psikologis pada ibu primigravida umumnya belum mempunyai bayangan mengenai kejadian-kejadian saat persalinan terjadi. Salah satu yang harus dipersiapkan ibu menjelang persalinan yaitu hindari kepanikan dan ketakutan dan bersifat tenang, dimana ibu hamil dapat melalui saatsaat persalinan dengan baik dan lebih siap serta meminta dukungan dari orang-orang terdekat, perhatian dan kasih sayang tentu akan membantu memberikan semangat untuk ibu yang akan melahirkan ${ }^{10}$.

\section{Pengaruh Senam Yoga Ibu Hamil} Terhadap Kesiapan Fisik dan Psikologis

Berdasarkan tabel 3 dapat dilihat bahwa sebagian besar responden yang melakukan senam yoga teratur mempunyai kesiapan fisik dan psikologis siap sebanyak 22 responden dan sebagian besar responden yang melakukan senam yoga tidak teratur mempunyai kesiapan fisik dan psikologis kurang siap sebanyak 11 responden. Hasil uji statistik dengan Chi-Square dengan $\alpha<0.05$ didapatkan $\mathrm{p}=0.00$ berarti kurang dari 0.05 maka dapat disimpulkan bahwa hipotesis diterima yang artinya ada hubungan yang bermakna antara senam yoga ibu hamil dengan kesiapan fisik dan psikologis dalam menghadapi persalinan di BPM Lasmitasari, S.ST Tahun 2016.

Menurut Stoppard yoga adalah cara yang baik untuk mempersiapkan persalinan karena teknik latihannya menitikberatkan pada pengendalian otot, teknik pernafasan relaksasi dan ketenangan pikiran. Teknik relaksasi yang dapat dilakukan dengan cara membayangkan sesuatu yang menyenangkan dapat membuat tubuh menjadi rilek ${ }^{14}$. Senam hamil yoga bagi kehamilan memfokuskan perhatian pada ritme nafas, mengutamakan kenyamanan serta keamanan dalam berlatih sehingga memberikan banyak manfaat ${ }^{8}$.

Manfaat yoga bagi kesehatan dapat menurunkan tekanan darah, detak jantung dan meningkatkan peredaran darah untuk membuang sisa-sisa makanan yang mengandung racun bagi tubuh. Manfaat senam hamil yoga pada ibu hamil yaitu dapat meningkatkan aliran darah dan nurtrisi bagi janin secara adequat serta berpengaruh juga pada organ reproduksi dan panggul (memperkuat otot perineum) ibu untuk 
mempersiapkan kelahiran anak secara alami. Selain itu latihan yoga selama hamil dapat mengurangi edema dan kram yang sering terjadi pada bulan-bulan terakhir kehamilan, membantu posisi bayi dan pergerakan, meningkatkan sistem pencernaan dan nafsu makan, meningkatkan energi dan memperlambat metebolisme untuk memulihkan ketenangan dan fokus, mengurangi rasa mual, morning sicnkness dan suasana hati,meredakan ketegangan di sekitar leher rahim dan jalan lahir, yang berfokus pada pembukaan pelvis untuk mempermudah persalinan, membantu dalam perawatan pasca kehamilan dengan mengembalikan uterus, perut dan dasar panggul, mengurangi ketegangan, cemas dan depresi selama hamil, persalinan nifas dan ketidaknyamanan payudara ${ }^{9}$.

\section{Kesimpulan dan Saran}

Hasil penelitian dari 40 responden diperoleh kesimpulan yaitu:

1. Ibu hamil yang melakukan senam yoga secara teratur sebanyak 25 responden $(62.5 \%)$

2. Sebagian besar kesiapan fisik dan psikologis ibu hamil siap menghadapi persalinan yaitu 26 responden $(65 \%)$.

3. Ada Pengaruh antara senam ibu hamil terhadap kesiapan fisik dan psikologis dalam menghadapi persalinan $\mathrm{p}=0.00<\alpha$ $=0.05$.

Diharapkan dapat menjadi bahan untuk menambah pengetahuan mengenai senam yoga hamil dan ibu hamil bisa melakukan senam yoga hamil secara teratur karena senam yoga hamil mempunyai banyak manfaat bagi ibu hamil terhadap kesiapan fisik dan psikologis dalam menghadapi persalinan.

\section{Ucapan Terima Kasih}

Peneliti ingin mengucapkan terima kasih yang tiada terhingga kepada pembimbing utama dan pembimbing pendamping yang telah banyak membantu peneliti dalam menyelesaikan Karya Tulis Ilmiah dan banyak memberikan masukan dan saran dalam menyelesaikan Karya Tulis Ilmiah ini.

\section{Daftar Pustaka}

1. Kementerian Kesehatan Republik Indonesia. Situasi Kesehatan Ibu [Internet]. Pusat Data dan Informasi Kementrian Kesehatan Republik Indonesia. 2014. p. 8. Available from: www.depkes.go.id/resources/download /pusdatin/infodatin/infodatin-ibu.pdf
Anggara
D. Hubungan Faktor

Demografis, Psikologis Ibu dan Organisasi dengan Pemanfaatan Pelayanan Jaminan Persalinan (Jampersal) Tahun 2013 di Kecamatan Beringin Kabupaten Deli Serdang. Universitas Sumatera Utara; 2014.

3. Perry SE, Hockenberry MJ, Lowdermilk DL, Wilson D. Maternal Child Nursing Care, 4th Edition. 
Ni Wayan Kurnia Widya Wati, Salasiah Supiyati, Khairiatul Jannah, Pengaruh Senam Yoga terhadap Kesiapan Fisik dan Psikologis dalam Menghadapi Persalinan di BPM Lasmitasari, S.ST

Mosby: Elsevier; 2010.

4. Knowledge R. Insomnia dan Gangguan Tidur Lainnya. Jakarta: PT.

Elex Media Komputindo; 2004.

5. Perry SE, Lowdermilk DL. Maternity Nursing (7th, Seventh Edition). Mosby: St. Louis; 2004.

6. Beddoe AE, Yang C-PP, Kennedy HP, Weiss SJ, Lee KA. The Effects of Mindfulness-Based Yoga During Pregnancy on Maternal Psychological and Physical Distress. J Obstet Gynecol Neonatal Nurs [Internet]. 2009;38(3):310-9. Available from: http://jognn.awhonn.org

7. Rusmita E. Pengaruh Senam Hamil Yoga Selama Kehamilan Terhadap Kesiapan Fisik dan Psikologis Dalam Menghadapi Persalinan Pada ibu Hamil Trimester III di Rumah Sakit Ibu dan Anak Limijati Bandung. Universitas Indonesia; 2015.

8. Krisnadi SR. Yoga untuk Kehamilan: Sehat, Bahagia, dan Penuh Makna [Internet]. Jakarta: Qanita; 2010. Available from: http://www.bukukita.com

9. Wiadnyana MS. The Power Of Yoga For Pregnancy and Post-Pregnancy. Jakarta: Taruna Grafika; 2011.

10. Indiarti MT. Pendahuluan Lengkap Kehamilan, Persalinan dan Perawatan Bayi (10th ed). Yogyakarta: Diglossia Media; 2009.

11. Hariyanto M. Pengaruh Senam Yoga
Terhadap Tingkat Kecemasan Ibu Hamil Trimester III di Praktik Bidan Mandiri Kabupaten Boyolali. Universitas Muhammadiyah Surakarta; 2015.

12. Widdowson R. Yoga for Pregnancy. London: Heron Quays Dockland; 2001.

13. Basford L, Slevin O. Teori dan Praktik Keperawatan Pendekatan Integral Pada Asuhan Pasien. Jakarta: Gramata; 2006.

14. Stoppard M. Conception Pregnancy and Birth: Ensiklopedia Kehamilan. Surabaya: Erlangga; 2008. 